\title{
Aspergillus flavus induced oxidative stress and immunosuppressive activity in Spodoptera litura as well as safety for mammals
}

\section{Dr. Mandeep Kaur}

Guru Nanak Dev University

Dr. Pooja Chadha ( $\nabla$ poojachadha77@yahoo.co.in )

Guru Nanak Dev University

\section{Dr. Sanehdeep Kaur}

Guru Nanak Dev University

\section{Dr. Amarjeet Kaur}

Guru Nanak Dev University

\section{Research Article}

Keywords: Spodoptera litura, Aspergillus flavus, Oxidative stress, Lipid peroxidation, Antioxidant enzymes, Haemocytes, cytotoxicity, Immunosuppressant, genotoxicity

Posted Date: March 22nd, 2021

DOI: https://doi.org/10.21203/rs.3.rs-32331/v3

License: (1) (1) This work is licensed under a Creative Commons Attribution 4.0 International License. Read Full License

Version of Record: A version of this preprint was published at BMC Microbiology on June 14th, 2021. See the published version at https://doi.org/10.1186/s12866-021-02249-4. 


\section{Abstract}

Background: In the last few decades, considerable attention has been paid to entomopathogenic fungi as biocontrol agents, however little is known about their mode of action and safety. This study aimed to investigate the toxicity of Aspergillus flavus in insect Spodoptera litura by analyzing the effect of fungal extract on antioxidant and cellular immune defense. In antioxidant defense, the lipid peroxidation (Malondialdehyde content) and antioxidant enzymes activities (Catalase, Ascorbate peroxidase, Superoxide dismutase) were examined. In cellular immune defense, effect of $A$. flavus extract was analyzed on haemocytes using Scanning Electron Microscopy (SEM). Furthermore, mammalian toxicity was analyzed with respect to DNA damage induced in treated rat relative to control by comet assay using different tissues of rat (blood, liver, and kidney).

Results: Ethyl acetate extract of A. flavus was administrated to the larvae of S.litura using artificial diet method having concentration $1340.84 \mu \mathrm{g} / \mathrm{ml}$ ( $\mathrm{LC}_{50}$ of fungus). The effect was observed using haemolymph of insect larvae for different time intervals $(24,48,72$ and 96). In particular, Malondialdehyde content and antioxidant enzymes activities were found to be significantly $(p \leq 0.05)$ increased in treated larvae as compared to control. A. flavus ethyl acetate extract also exhibit negative impact on haemocytes having major role in cellular immune defense. Various deformities were observed in different haemocytes like cytoplasmic leakage and surface abnormalities etc. Genotoxicity on rat was assessed using different tissues of rat (blood, liver, and kidney) by comet assay. Non-significant effect of $A$. flavus extract was found in all the tissues (blood, liver, and kidney).

Conclusions: Overall the study provides important information regarding the oxidative stress causing potential and immunosuppressant nature of $A$. flavus against $S$. litura and its non toxicity to mammals (rat), mammals (rat), suggesting it an environment friendly pest management agent.

\section{Background}

Food security and environment safety are the major concerns in ever expanding human population on the earth planet. Each and every year insect pests cause a severe damage in agricultural field which cost billions of dollars annually to farmers. To reduce the crop damage due to insect pests, the reliance on chemical pesticides has increased. However, irrespective use of chemical pesticides such as Endosulfan, Benzene hexachloride, Aldicarb, and Fenobucarb in agricultural field raised several types of issues include their non-biodegradable nature, development of insecticide resistance and adverse effects on human health as well as environmental concerns [1]. Overall, synthetic pesticides wreak havoc on the environment, threatening biodiversity and human survival [2]. Thus, there is a need to explore alternative ecofriendly strategies for pest's management which protect and strengthen natural ecosystems rather than contaminate.

Biological control using fungi is one of the most promising technique, due to their unique mechanism of action while infection, low cost, specificity and safety to ecosystem [3, 4]. Entomopathogenic fungi are natural pest controlling agents manifesting immense significance to be used as mycoinsecticides against 
wide range of insect pests. Among entomopathogenic fungi Beauveria bassiana and Metarhizium anisopliae have been extensively explored as insecticidal agents and their formulations are also commercially available. Moreover various other fungal spp. viz Aspergillus sp., Alternaria sp. and Nomuraea sp. have also been disclosed to be entomopathogenic [5-8]. Different Aspergillus spp. viz A. ochraceus, $A$. kanagawaensis, $A$. sulphureus, $A$. flavus and $A$. ochraceus were found to be pathogenic against several insects such as Aedes fluviatilis (Lutz), Culex quinquefasciatus (Say), Anopheles gambiae (Giles), Oligonychus coffeae (Nietner) [9-12]. The insecticidal activity of fungi could be attributed to different secondary metabolites produced by them. Mycotoxins viz aflatoxins, ochratoxins, fumonisins, zearalenone, have great importance in agriculture for pest management [13]. Various fungal secondary metabolites like avermectins, destruxins, pantherine, ibotenic acid, and tricholomic acid were found to be highly active against insects [14].

Although various studies have been done on the role of fungi as an insect pathogenic agents but many of them failed to address the mode of action. In order to discover the insecticidal potential, the effect on antioxidant and cellular immune defense in insects would be evaluated. Insects possess antioxidant and cellular immune defense system to ward of infection. Antioxidant defense system comprises various antioxidants enzymes which are catalase (CAT), glutathione-S-transferases (GSTs), peroxidase (POX), and superoxide dismutase (SOD). All these play an important role in protecting cells and maintaining homeostasis by removing oxidative stress [15]. Various xenobiotics incite the production of reactive oxygen species (ROS) cause the oxidative stress which ultimately induces oxidative damage, cytotoxicity or immunotoxicity and an increase in insects' mortality [16]. Cellular immune defense in insects is accomplished through haemocytes. They consists the mixture of cells having different morphological and biological functions and help in providing defense against parasites, pathogens and other foreign bodies enter in the hemocoel [17-20]. Change in number and configuration of haemocytes ultimately affect the immunity and health of insects [21]. So, these parameters are significant while estimating the stress caused by xenobiotics.

On the basis of aforementioned discussion, the study examines the toxicity of ethyl acetate extract of $A$. flavus on insect Spodoptera litura (Fabricius), one of the major polyphagous pests, by analyzing the effect on antioxidant and cellular immune defense of insect

However, if secondary metabolites of fungi are found to deter insects then it would be equitably important to detect whether these metabolites have any mammalian toxicity. As, various chronic diseases have been associated with pesticides exposures, including reproductive or developmental disorders, neurological disorders, cancer etc. Epidemiological studies suggested that occupationally exposed populations to pesticides like pesticide applicators, pesticide manufacturing workers and field workers have developed the high risk of cancer which is due to genomic damage [22-24]. So it is necessary to check genotoxicity of the agent which can be used as pesticide in order to decipher its effects on other non-target species. Various genotoxic markers are chromosomal abbretions (CA), sister chromatid exchange (SCE), micronuclei (MN), comet assay (CO). Comet assay or SCGE is one of the finest techniques for qualitative and quantitative analysis of DNA damage and repair. It was extensively explored in mammal and human cell studies [25-27] and successfully applied on the cells of various animal groups [28]. So in the present study this technique 
was used to assess the genotoxicity of $A$. flavus on mammals using rat as an animal model to confirm its safety on mammals.

\section{Results}

\section{Toxicity test of fungus and LC50 value against S.litura:}

The entomopathogenic fungus, $A$. flavus was tested at different concentrations for toxicity against larvae of $S$. litura. The mortality percentages were proportional to extract concentration as shown in table. 1. Different concentrations of the extract caused $16.66-56.66 \%$ mortality as compared to $10 \%$ in control. The concentrations ranging between $500-2000 \mu \mathrm{g} / \mathrm{ml}$ resulted in a significantly higher mortality with respect to control $(\mathrm{F}=8.38, \mathrm{p} \leq 0.01)$ (table. 1). The LC50 value of ethyl acetate extract of $A$. flavus as calculated by probit analysis using SPSS software was found to be $1340.84 \mu \mathrm{g} / \mathrm{ml}$.

\section{Effect on Malondialdehyde (MDA) content and antioxidant enzymes:}

Larvae treated with ethyl acetate extract of $A$. flavus showed hike in level of lipid peroxidation as indicated by MDA content which significantly increased in all treated groups as compared to control in haemolymph of $S$. litura (Student's t-test) except for $24 \mathrm{hr}$ group in which non-significant increase was observed. MDA content was maximum at $96 \mathrm{hr}(8.76 \pm 0.16 \mathrm{nmoles} / \mathrm{ml})$ which was significantly higher from control $(5.75 \pm 0.13 \mathrm{nmoles} / \mathrm{ml})(\mathrm{t}=14.80, \mathrm{p} \leq 0.01)$. One Way ANOVA reveals the effect of duration was found to be significant $(F=76.14, p \leq 0.01)$. Further Tukey's test reveals the significant difference between 48,72 and 96hr exposure groups (Fig. 1a).

Statistically significant ( $t$ test, $p \leq 0.05)$ increase in activities of all enzymes with respect to control of the exposed S.litura larvae was observed. Fig. $2 \mathrm{~b}$ reflected the significant ( $t$ test, $\mathrm{p} \leq 0.05$ ) hike in catalase (CAT) activity of treated larvae as compared to control. A measured value of CAT was 3 fold higher than control one, for $96 \mathrm{hr}$ exposure time group. The difference between all exposure time groups was statistically significant (ANOVA) and significant difference observed between $48 \mathrm{hr}, 72 \mathrm{hr}$ and $96 \mathrm{hr}$ groups (Tukey's test) (Fig. 1b).

An upsurge in Ascorbate peroxidase (APOX) activity was noticed in haemolymph of $S$. litura after treatment with A.flavus ethyl acetate extract. The level of enzyme activity was found to be $67.77 \pm 0.34,82.20 \pm 3.23$, $87.42 \pm 0.56,125.80 \pm 4.59 \mu \mathrm{mole} / \mathrm{ml}$ following treatment up to $24 \mathrm{hr}, 48 \mathrm{hr}, 72 \mathrm{hr}$ and $96 \mathrm{hr}$ respectively. Highest activity was found in $96 \mathrm{hr}$ exposure group where almost 3.74 fold increase was observed in treated groups as compared to control $(t=19.60, p \leq 0.01)$. Time dependent significant effect was observed (ANOVA) $(F=76.81, p \leq 0.01)$ however significant changes were observed between $24 \mathrm{hr}$ and $48 \mathrm{hr}, 72 \mathrm{hr}$ and $96 \mathrm{hr}$ exposure groups (Tukey's test) (Fig. 1C).

Superoxide dismutase (SOD) activity also found to be increase in larvae fed with diet amended with ethyl acetate extract of $A$. flavus (Fig. 1d). Significant ( $t$ test, $p \leq 0.05$ ) rise in SOD activity was occurred in all exposure groups as compared to control however highest activity was obtained at $72 \mathrm{hr}$ and $96 \mathrm{hr}$ exposure groups where activity increased from $28.19 \pm 0.17 \mu \mathrm{mol} / \mathrm{ml}$ (control) to $41.54 \pm 0.87 \mu \mathrm{mol} / \mathrm{ml}$ (exposed group) 
and $28.33 \pm 0.18 \mu \mathrm{mol} / \mathrm{ml}$ (control) to $51.68 \pm 0.88 \mu \mathrm{mol} / \mathrm{ml}$ (exposed group) respectively. With increase in time duration the enzyme activity was significantly increased (ANOVA) $(F=202.57, p \leq 0.01)$. Significant difference observed between 48hr, 72hr and 96hr exposure groups (Tukey's test) (Fig. 1d).

\section{Effect on haemocytes:}

The scanning electron microscopy studies revealed that the haemocytes of S.litura were changed very apparently after treatment with A.flavus ethyl acetate extract (Fig. 2, 3, 4). After $96 \mathrm{hr}$ various morphological deformities were observed in different haemocytes. As compared to normal haemocytes (Group-1) treated ones showed cell perforation and cytoplasmic leakage (Fig.2). Similarly, normal haemocytes of Group-2 not shown any deformity but treated ones showed strumae and surface abnormalities (Fig.3). Group -3 haemocytes showed surface abnormalities after treatment with A.flavus (Fig.4). Overall SEM studies revealed that morphology of haemocytes was highly disrupted after treatment with ethyl acetate extract of $A$.flavus for $96 \mathrm{hr}$ which might be leads to cytotoxicity.

Relative to the control, the percentage of haemocytes with various deformities were found to be significantly increased in treated larvae due to the toxic effects of fungal extract. After $96 \mathrm{hr}$ of feeding, the percentage of cells having various deformities were $78.33 \%$ as compared to $8.33 \%$ in control (Fig. 5).

\section{Mammalian toxicity:}

Comet assay was conducted to assess genotoxicity on rat using parameters, Tail length, \% Tail DNA, Tail Moment and Olive Tail Moment. The obtained data in Table 2, 3, 4 showed that there were no significant differences in all the parameters after 24 and $96 \mathrm{hr}$ of rat's administration with A.flavus extract at dose level of $100 \mathrm{mg} / \mathrm{kg}$ body weight and $200 \mathrm{mg} / \mathrm{kg}$ body weight relative to control (ANOVA). In case of rat blood non-significant increase was observed for all the parameters except in case of tail length of $96 \mathrm{hr}$ group where significant increase was observed from $14.78 \pm 0.13$ (control) to $15.51 \pm 0.11$ ( $200 \mathrm{mg} / \mathrm{kg} \mathrm{b.wt).} \mathrm{In} \mathrm{all}$ other groups non-significant increase was observed after treatment with different concentrations of $A$. flavus (Table. 2). Similarly in rat liver non-significant effect was obtained for all the parameters after treatment with both concentrations ethyl acetate extract of $A$. flavus (ANOVA) (Table. 3). In rat kidney all parameters showed non-significant increase except tail length of $24 \mathrm{hr}$ group and \%tail DNA of $96 \mathrm{hr}$ group where significant increase was observed (Table. 4). Effect of duration was also found to be non-significant in all the tissues as revealed by student's t-test. Overall non-significant effect was observed.

Photomicrographs showing DNA damage in different tissues of rat after treatment with $A$. flavus fungal extracts are shown in fig. 6 .

\section{Discussion}

In the last few decades, entomopathogenic fungi have attracted considerable attention as biocontrol agents in sustainable agriculture. They are known to have several advantages as compared to synthetic pesticides. To date, several studies have indicated the fungal agents as insect pathogens $[30,38,5,6]$. So, in the present study secondary metabolites of $A$. flavus were extracted using ethyl acetate and tested for their toxicity on insect, Spodoptera litura. Ethyl acetate extract was found to exhibit negative impact on larval 
survival. Previously various species of Aspergillus are found to be entomopathogenic like A.flavus, A.oryzae, A.tamarii and A.versicolor, A.parasititus etc. $[5,6,39,40]$. Two strains of $A$. flavus named as $A$. flavus NRRL and $A$. flavus AF36 are commercially available as biocontrol agents [41, 42]. Their active ingredients are being used in various pesticides which also help in reducing aflatoxin contamination in crops.

To decipher the mode of action the effect on antioxidant and cellular immune response was studied. Insects have evolved multiple defense mechanisms including antioxidant and cellular immune defense, to respond to pathogens. Antioxidant defense systems in insects include various antioxidant enzymes viz Catalase (CAT), Ascorbate peroxidase (APOX), Superoxide dismutase (SOD) and Glutathione-S-Transferase (GST). All work co-coordinately to maintain the state of dynamic equilibrium in organism, keeping ROS low level to prevent the cells from damage $[43,44]$. Increase in malondialdehyde (MDA) content and antioxidant enzymes activity is an important indicator of oxidative stress. MDA is the product formed during lipid peroxidation (LP) which cause DNA damage and cell death [45]. So, in this study, the MDA content and activities of antioxidant enzymes were determined in Spodoptera litura larvae at different times, after treatment with ethyl acetate extract of A.flavus, in order to speculate A.flavus induced oxidative stress and effect on antioxidant defense. Results showed significant increase in MDA level in response to fungal extract as compared to control. At $96 \mathrm{hr}$ value increased 1.5 times as compared to control. This finding is in corroboration with the finding of Karthi et al. [12] revealing the toxic effects of Aspergillus flavus spores on S.litura.

The activities of antioxidant enzymes are also found to be significantly increased after exposure to A.flavus extract, showing influence of fungus on antioxidant defense of insect. CAT and APOX activities increased 3.00 and 3.74 fold respectively, however, SOD activity was found to be increased 1.82 fold as compared to control, at $96 \mathrm{hr}$, in haemolymph of $S$. litura. This might be due to activation of host response after toxicity induced by A.flavus, in which enzymes activities were remarkably accelerated to metabolize the ROS, reaching the maximum value at $96 \mathrm{hr}$. Similar increase in antioxidant enzymes activities [superoxide dismutase (SOD), catalase (CAT), peroxidases (POX)] was observed by Karthi et al. [12] under the influence of $A$. flavus spores. Scarce reports recorded the effect of fungal agents on protective enzymes activities. Ding et al. (2015) observed the increase in protective enzymes activity in Xylotrechus rusticus (Linnaeus) under the influence of B. bassiana. M. anisopliae also found to alter the antioxidant and detoxifying enzymes activities in Periplaneta americana (Linnaeus) and Locusta migratoria (Linnaeus) [46-48]. Chaurasia et al. [49] observed variable activity of antioxidant enzymes in P. americana under the influence of entomopathogenic fungus Hirsutella thompsonii. However alteration in enzymes activities due to different chemicals and other stress factors in insects has been reported by many studies [50-54].

Cellular response in insect immune system acts as an important barrier to the infection process [55-56]. Haemocytes types and their specific responses while insect-pathogen interaction act as a good indicators of insect defense reactions [57-58]. There are different types of haemocytes which have been morphologically and functionally characterized in various insects [59-61]. Multifunctional role of haemocytes are phagocytosis, encapsulation, cell agglutination, detoxification etc. Change in number and configuration was observed in haemocytes under different stresses which ultimately affect the health of 
insects. Consequently these cells have been used to ascertain the cytogenetic damage by toxic chemicals $[62,63]$.

So, in our investigation effect on cellular immune response was also judged by analyzing effect on haemocytes by scanning electron microscopy. SEM results showed various cellular deformities in different haemocytes like cell perforation, cytoplasmic leakage, strumae and surface abnormalities after treatment with ethyl acetate extract of A.flavus as compared to control. The results are in corroboration with study of Fan et al. [64] which observed the cell perforation and rupturing with cytoplasmic leakage in haemocytes of Bombyx mori (Linnaeus) after treatment with destruxin A. There are very few studies which reveal the abnormalities of insect haemocytes using SEM, however technique has been used by various researchers to observe and characterize the different types of haemocytes in insects $[65,66]$ and to observe spores accumulation in insect's body after fungal infection $[5,6,67]$. Recently Duan et al. [68] observed the infection of $B$. bassiana to Leptinotarsa decemlineata (Say) via scanning electron microscopy. However the morphological changes observed in present study were demonstrated by various workers due to entomopathogenic fungi and insecticides under light microscopy [69-71].

Mammalian toxicity of A.flavus was carried out by assessing DNA damage in blood, liver and kidney of rat. Non-significant effect was observed in all the tissues of fungal extracts treated rats as compared to control. Similarly negligible toxicity of azadirachtin, a neem biopesticides was earlier reported in rats [72] and human [73]. There are few other botanical extracts which were also checked for their toxicity on rat such as Cassia senna, Caesalpinia gilliesii, Thespesia populnea, Chrysanthemum frutescens, Euonymus japonicus, Bauhinia purpurea, and Cassia fistula extracts [74], Dichaetanthera africana extract [75]. Toxicity of fungal extracts on mammals was not checked previously however, Sprando et al. [76] reported the safety of bacterial species Paenibacillus alvei to rat.

\section{Conclusion}

Overall, the study highlights the adverse effect of $A$. flavus on the physiology of S.litura which might be due to the negative impact on antioxidant and cellular immune defense of an insect. The study helps to identify the insect defenses that could be manipulated to accelerate host death in biological control scenario. The study also showed its safety for mammals as it showed negligible toxicity on rat, suggesting it to be used as bio-pesticide after further field studies.

\section{Methods}

Insects rearing:

Spodoptera litura (Lepidoptera) eggs were obtained from the cauliflower fields around Amritsar (India). After hatching of eggs larvae were fed on castor leaf. Subsequent generations of culture were maintained in laboratory at $25 \pm 2 \varangle \mathrm{C}$ temperature, $65 \pm 5 \%$ relative humidity and 12:12 (D: L) photoperiod [29].

\section{Fungal culture isolation, production and identification}


Fungus was isolated from the surface of dead insect (Kaur et al. 2019). The production was carried out in $50 \mathrm{ml}$ malt extract (malt extract $=20 \mathrm{~g} / \mathrm{l}$, dextrose $=20 \mathrm{~g} / \mathrm{l}$,peptone $=1 \mathrm{~g} / \mathrm{l}, \mathrm{pH}=5.5$ ) broth in $250 \mathrm{ml}$ Erlenmeyer flask by inoculating one plug ( $1 \mathrm{~cm}$ square) taken from the periphery of an actively growing culture. The flasks were incubated at $30^{\circ} \mathrm{C}$ and $250 \mathrm{rpm}$ for 10 days. After 10 days extraction was carried out twice using ethyl acetate at $120 \mathrm{rpm}$ and $40^{\circ} \mathrm{C}$. The extracts were concentrated by using rotavapor and dissolved in $1 \mathrm{ml}$ DMSO and stored at $4 \llbracket \mathrm{C}$.

The fungus was identified as Aspergillus flavus on morphological (Fig S1: Morphology of A.flavus showing, Hyphae and Conidiophore under SEM) and molecular basis as indicated in our previous study [30] by using ITS1 and ITS4 primer to amplify ITS1-5.8S- rDNA- ITS2 region. Amplified ITS region was Purified and sequenced at first base sequencing (Malaysia). The sequence similarity was matched with other available databases retrieved from NCBI using BLAST [31]. The sequence was submitted to GeneBank under the accession number MF680839 [30].

\section{Toxicity test of fungus and LC50 value against S.litura:}

Toxicity of fungus was tested by checking mortality rate. For this different concentrations $(125,250,500$, 1000 and $2000 \mu \mathrm{g} / \mathrm{ml}$ ) of fungal extract were made in $0.5 \%$ DMSO and added in artificial diet. The Second instar larvae ( 6 days old) were reared on fungal extract amended diets as well as with control diet $(0.5 \%$ DMSO) at controlled temperature $25 \pm 2 \varangle \mathrm{C}$ and relative humidity $70 \pm 5 \%$ conditions. The experiment was replicated six times with five larvae per replication. Each larva was put in separate container $(4 \times 6 \mathrm{~cm})$ and the diet was changed daily till pupation. Dead larvae were checked daily till pupation. The total numbers of dead larvae were counted. The toxic effect of fungal extract on S.litura was calculated using the probit analysis $\mathrm{LC}_{50}$ (lethal concentration) determination method.

\section{Effect on Malondialdehyde (MDA) content and antioxidant enzymes activity:}

To evaluate the effect of fungal extracts on lipid peroxidation and antioxidant enzymes, the third instar larvae (12 days old) were fed with fungal extracts supplemented diet having concentration $1340.84 \mu \mathrm{g} / \mathrm{ml}$ ( $\mathrm{LC}_{50}$ of fungus). The MDA content and enzymes activities [Superoxide dismutase (SOD), catalase (CAT), Ascorbate peroxidase (APOX)] were analyzed in haemolymph of third instar (12days) larvae.

Larvae were divided into two groups, treatment and control. Treatment group was treated with $\mathrm{LC}_{50}$ of fungus at controlled temperature $25 \pm 2 \llbracket \mathrm{C}$ and relative humidity $65 \pm 5 \%$. The second group was treated with control diet (0.5\% DMSO) at same conditions of temperature and relative humidity. The effect of fungal extract has been recorded after different time intervals $(24 \mathrm{hr}, 48 \mathrm{hr}, 72 \mathrm{hr}$ and $96 \mathrm{hr})$ in lipid peroxidation and enzyme activities. The experiment was replicated three times. For each treatment and control there are 10 larvae per replication were taken.

\section{Tissue collection}

Haemolymph was collected by cutting proleg with microscissor from 10 different larvae fed with same concentration and then it was pooled. Pooled haemolymph (10\%) was mixed with PBS (Phosphate Buffer 
Saline $\mathrm{pH} 7.0$ ) containing $0.01 \%$ phenylthiourea and centrifuged for $20 \mathrm{~min}$ at $10000 \mathrm{~g}, 4^{\circ} \mathrm{C}$ and supernatant obtained was used for enzyme activities studies

The extraction procedure was same for lipid peroxidation and all enzymes.

\section{Malondialdehyde (MDA) content:}

MDA content was measured according to Jain and Levine [32] with slight modifications. MDA content as an indicator of lipid peroxidation was determined after incubation of $0.5 \mathrm{ml}$ of sample (supernatant) at 95 ${ }^{\circ} \mathrm{C}$ with Trichloroacetic acid (TCA) $(20 \% \mathrm{w} / \mathrm{v})$, Thiobarbituric acid (TBA) $(1 \% \mathrm{w} / \mathrm{v})$. Absorbance was taken at $532 \mathrm{~nm}$ against the blank. MDA content was expressed as nanomole $/ \mathrm{ml}$ by using $1.56 \times 10^{5} \mathrm{M}^{-1} \mathrm{~cm}^{-1}$ extinction coefficient.

\section{Catalase (CAT) activity:}

Enzyme activity was estimated according to methodology given by Aebi [33] with slight modifications. $0.1 \mathrm{ml}$ of supernatant was added into $2.9 \mathrm{ml}$ of $\mathrm{H}_{2} \mathrm{O}_{2}$ in a cuvette. Decrease in absorbance was read at $240 \mathrm{~nm}$ for $5 \mathrm{~min}$ at $1 \mathrm{~min}$ interval $(25 \llbracket \mathrm{C})$. The enzyme activity was expressed as $\mu \mathrm{M} / \mathrm{ml}$ (haemolymph).

\section{Ascorbate peroxidase (APOX) activity:}

The enzyme activity was calculated according to methodology given by Asada [34] with slight modifications. $0.1 \mathrm{ml}$ of sample, $0.6 \mathrm{ml}$ extraction buffer and $0.125 \mathrm{ml}$ of $0.3 \% \mathrm{H}_{2} \mathrm{O}_{2}$ were taken in cuvette.

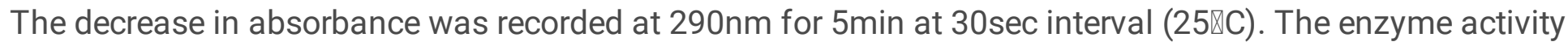
was expressed as $\mu \mathrm{M} / \mathrm{ml}$ (haemolymph).

\section{Superoxide dismutase (SOD) activity:}

The enzyme activity was calculated according to methodology given by Kono [35] with slight modifications. $0.05 \mathrm{ml}$ sample, $1.5 \mathrm{ml}$ sodium carbonate buffer, $0.5 \mathrm{ml}$ NBT (Nitroblue tetrazolium), $0.1 \mathrm{ml}$ TritonX-100, $0.1 \mathrm{ml}$ hydroxylamine hydrochloride were taken in cuvette and increase in absorbance was recorded at $540 \mathrm{~nm}$. The enzyme activity was expressed as $\mu \mathrm{M} / \mathrm{ml}$ (haemolymph).

\section{Effect on haemocytes:}

Haemolymph was collected and pooled from 10 larvae fed with same concentration. Effect on haemocytes was studied by scanning electron microscopy (SEM).

\section{Scanning electron microscopy (SEM):}

SEM was done according to methodology of Wang et al. [36] with slight modifications. Haemolymph was bled on termanox discs after cutting proleg of larvae. It was allowed to dry and fixed with $2.5 \%$ glutaraldehyde in $0.1 \mathrm{M}$ cacodylate buffer $(\mathrm{pH} 7.2)$ for two hours. After this sequential dehydration was done by using graded series of ethanol i.e $25 \%$ followed by $50 \%, 70 \%, 90 \%$ and at the end with absolute $(100 \%)$ alcohol. Then discs were placed in dry chamber for proper drying. At the end silver coating was 
done by mounting samples on aluminium stubs and haemocytes were observed under SEM at magnification of $10.00 \mathrm{KX}$ operated at $10 \mathrm{KV}$ after $96 \mathrm{hr}$ of treatment with fungal extracts.

\section{Mammalian toxicity study:}

Sexually mature male wistar albino rats having weight $120 \pm 20 \mathrm{gm}$ were used in study. Animals were reared on commercial pellet diet and water adds libitum and housed in cages at particular temperature $(25 \pm 2 \varangle \mathrm{C})$ and humidity conditions (50-60\%). The rats were brought from private source. All experiments were performed according to guidelines provided of Institutional Animal Ethics Committee (IAEC) of Guru Nanak Dev University, Amritsar, Punjab (India). The application for permission for animal experiments was submitted to the CPCSEA, New Delhi and after approval of Institutional Animal Ethics Committee (IAEC) got Registration number: 226/PO/Re/S/2000/CPCSEA. The animals were acclimatized 5 days before experiments. Two concentrations $100 \mathrm{mg} / \mathrm{kg}$ b.wt and $200 \mathrm{mg} / \mathrm{kg}$ b.wt of fungal extracts were selected for experiments and effects were studied after $24 \mathrm{hr}$ and $96 \mathrm{hr}$ of exposure. The A.flavus fungal extract dissolved in $0.5 \% \mathrm{DMSO}$ was injected intraperitoneally to the rat. The experiment was replicated thrice and DNA damage was assessed by comet assay according to methodology given by Ahuja and Saran [37] in different tissues viz. blood, liver and kidney. Rats were sacrificed using gas inhalation method. Blood samples $(1 \mathrm{ml})$ were taken directly from heart and used as such after adding anticoagulant however two tissues i.e. liver, kidney were homogenized in PBS and centrifuged at 10,000g for $10 \mathrm{~min}$. Cell suspension was taken and used for DNA damage study.

\section{Statistical analysis:}

To study the effect of duration one way analysis of variance (ANOVA) with Tukey's test was performed and to study the effect of treatment student's t-test was applied

\section{Abbreviations}

CAT: Catalase; APOX: Ascorbate peroxidase; SOD: Superoxide dismutase; GST: Glutathione- S-Transferase

\section{Declarations}

Ethics Approval and Consent to Participate: This article contains studies involving animals. Rats were used after getting permission from animal ethical committee

\section{Acknowledgement:}

The grants received from UGC (University Grant Commission), New Delhi, India under SAP (Special Assistance Program) and UPE schemes are thankfully acknowledged.

Competing Interest: All authors declare that they have no conflict of interest. Consent for publication: Not applicable. 
Availability of data and materials: All data generated or analyzed during this study are included in this article and its additional files.

Funding: This work was supported by Grant from UGC (University Grant Commission) - SAP (Special Assistance Program) and UPE grants.

Grant number of SAP- No.F.4-4/2016/DRS-I (SAP-II).

Funding bodies had no roles in study design and collection, analysis, and interpretation of data, or preparation of the manuscript.

Authors' contributions: PC, AK and SK designed the study and analyzed the content. MK performed the experiments and analyzed the content related to it. All authors have read and approved the manuscript.

\section{References}

1. Nicholson, Graham M. (2007). Fighting the global pest problem: preface to the special Toxicon issue on insecticidal toxins and their potential for insect pest control. Toxicon49: 4: 413-422.

2. Aktar, W., Sengupta, D. and Chowdhury A. (2009). Impact of pesticides use in agriculture: their benefits and hazards. Interdiscip toxicol. 2(1): 1-2.

3. Castillo, M. A., Moya, P., Hernández, E. and Primo-Yufera, E. (2000). Susceptibility of Ceratitis capitata Wiedemann (Diptera: Tephritidae) to entomopathogenic fungi and their extracts. Contro/19(3): 274282.

4. Charnley, A. K. and Collins, S. A. (2007). 10 Entomopathogenic Fungi and Their Role in Pest Control. Environmental and Microbial Relationships4: 159-165.

5. Bawin, T., Seye, F., Boukraa, S., Zimmer, J. Y., Raharimalala, F. N., Zune, Q. and Francis, F. (2016a). Production of two entomopathogenic Aspergillus species and insecticidal activity against the mosquito Culex quinquefasciatus compared to Metarhizium anisopliae. Biocontrol Sci. Technol. 26(5): 617-629.

6. Bawin, T., Seye, F., Boukraa, S., Zimmer, J. Y., Raharimalala, F. N., Ndiaye, M. and Francis, F. (2016b). Histopathological effects of Aspergillus clavatus (Ascomycota: Trichocomaceae) on larvae of the southern house mosquito, Culex quinquefasciatus (Diptera: Culicidae). Fungal Biol.120(4): 489-499.

7. Devi, P. V. (1994). Conidia production of the entomopathogenic fungus Nomuraea rileyi and its evaluation for control of Spodoptera litura (Fab) on Ricinus communis. . Invertebr. Pathol. 63(2): 145150.

8. Kaur, H. P., Singh, B., Kaur, A. and Kaur, S. (2013). Antifeedent and toxic activity of endophytic Alternaria alternata against tobacco caterpillar Spodoptera litura. Pest Sci.86(3): 543-550.

9. Lage, A. M., Moraes, G. L. and Costa, M. Z. (2001). The entomopathogenic potential of Aspergillus in mosquitoes vectors of tropical diseases. J. Basic Microbiol.41(1): 45-49.

10. Mazid, S., Rajkhowa, R. C. and Kalita, J. C. (2015). Pathogenicity of Aspergillus Niger and Aspergillus flavus on red spider mite (Oligonychus coffeae Nietner), a serious pest of tea. Entomol. Zool. 
Stud.3(3): 11-13.

11. Seye, F., Faye, O., Ndiaye, M., Njie, E. and Marie Afoutou, J. (2009). Pathogenicity of the fungus, Aspergillus clavatus, isolated from the locust, Oedaleus senegalensis, against larvae of the mosquitoes Aedes aegypti, Anopheles gambiae and Culex quinquefasciatus. Insect Sci.9(53): 1-7.

12. Karthi, S., Vaideki, K., Shivakumar, M. S., Ponsankar, A., Thanigaivel, A., Chellappandian, M. and SenthilNathan, S. (2018). Effect of Aspergillus flavus on the mortality and activity of antioxidant enzymes of Spodoptera litura(Lepidoptera: Noctuidae) larvae. Pestic. Biochem. Physiol. 149: 54-60.

13. Huffman J, Gerber R, Du L. Recent advancements in the biosynthetic mechanisms for polyketidederived mycotoxins. Biopolymers. 2010;93(9):764-776.

14. Busi S, Rajkumari J, Hnamte S. Feeding deterrence, acute toxicity and sublethal growth effects of kojic acid isolated from Aspergillus funiculosus. The Nat Prod J. 2014;4(1):18-22.

15. Rudneva, I. I. (1999). Antioxidant system of Black Sea animals in early development. Biochem. Physiol. C, Pharmacol. Toxicol. Endocrinol. 122(2): 265-271.

16. Freeman BA, Crapo JD. Biology of disease: free radicals and tissue injury. Lab invest; $\mathrm{j}$ techn met pathol. 1982;47(5):412-426.

17. Falleiros, Â. M. F., Bombonato, M. T. S. and Gregório, E. A. (2003). Ultrastructural and quantitative studies of hemocytes in the sugarcane borer, Diatraea saccharalis (Lepidoptera: Pyralidae). Arch. Biol. Technol.46(2): 287-294.

18. Ratcliffe, N. A. and Gagen, S. J. (1976). Cellular defense reactions of insect hemocytes in vivo: nodule formation and development in Galleria mellonella and Pieris brassicaeJ. Invert. Pathol. 28(3): $373-382$.

19. Ratcliffe, N. A., Rowley, A. F., Fitzgerald, S. W. and Rhodes, C. P. (1985). Invertebrate immunity: basic concepts and recent advances. rev. cytol.97: 183-350.

20. Lackie, A. M. (1988). Haemocyte behaviour. Insect Physiol. 21: 85-178.

21. Gayfullina, L. R., Saltykova, E. S. and Nikolenko, A. G. (2006). Cellular immune reactions participating in resistance formation of Colorado beetle (Leptinotarsa decemlineata Say) larvae and imago to a biopreparation for potato. Resistant Pest Manage News/15: 22-24.

22. Gangemi, S., Miozzi, E., Teodoro, M., Briguglio, G., De Luca, A., Alibrando, C. and Libra, M. (2016). Occupational exposure to pesticides as a possible risk factor for the development of chronic diseases in humans. med. rep.14(5): 4475-4488.

23. Rodgers, K. M., Udesky, J. O., Rudel, R. A. and Brody, J. G. (2018). Environmental chemicals and breast cancer: an updated review of epidemiological literature informed by biological mechanisms. res.160: 152-182.

24. Curl, C. L., Spivak, M., Phinney, R. and Montrose, L. (2020). Synthetic Pesticides and Health in Vulnerable Populations: Agricultural Workers. Environ. HealthRep. 7(1): 13-29.

25. Burlinson, B., Tice, R. R., Speit, G., Agurell, E., Brendler-Schwaab, S. Y., Collins, A. R. and Sasaki, Y. F. (2007). Fourth International Workgroup on Genotoxicity testing: results of the in vivo Comet assay workgroup. MUTATRES-GEN TOX EN 627(1), 31-35. 
26. Collins, A. R. and Azqueta, A. (2012). DNA repair as a biomarker in human biomonitoring studies; further applications of the comet assay. MUTAT RES-FUND MOL M 736(1-2): 122-129.

27. Collins, A., Koppen, G., Valdiglesias, V., Dusinska, M., Kruszewski, M., Møller, P. and Moretti, M. (2014). The comet assay as a tool for human biomonitoring studies: the ComNet project. MUTAT RES-REV MUTAT 759: 27-39.

28. Woźniak, K. and Blasiak, J. (2003). In vitro genotoxicity of lead acetate: induction of single and double DNA strand breaks and DNA-protein cross-links. Res. Genet. Toxicol. Environ. Mutagen 535(2) 127139.

29. Kaur, M., Chadha, P., Kaur, S., Kaur, A., Kaur, R., Yadav, A. K. and Kaur, R. (2018). Schizophyllum commune induced genotoxic and cytotoxic effects in Spodoptera litura. Scientific reports8(1): 1-12.

30. Kaur, M., Chadha, P., Kaur, S., Kaur, A., Kaur, R., Yadav, A. K. and Kaur, R. (2019). Evaluation of genotoxic and cytotoxic effects of ethyl acetate extract of Aspergillus flavus on Spodoptera litura. appl. microbiol.126(3): 881-893.

31. Sharma, M., Chadha, B. S., Kaur, M., Ghatora, S. K. and Saini, H. S. (2008). Molecular characterization of multiple xylanase producing thermophilic/thermotolerant fungi isolated from composting materials. Appl. Microbiol.46(5): 526-535.

32. Jain, S. K. and Levine, S. N. (1995). Elevated lipid peroxidation and vitamin E-quinone levels in heart ventricles of streptozotocin-treated diabetic rats. Free Radic. Biol. Med.18(2): 337-341.

33. Aebi, H. (1984). Catalase in vitro. Method Enzymol. 105: 121-126.

34. Asada, K. (1984). Chloroplasts: Formation of active oxygen and its scavenging. Method Enzymol.105: 422-429.

35. Kono Y. (1978). Generation of superoxide radical during autoxidation of hydroxylamine and an assay for superoxide dismutase. Biochem. Biophs. 86(1): 189-95.

36. Wang, Y., Hu, M., Chiang, M. W. L., Shin, P. K. S. and Cheung, S. G. (2012). Characterization of subpopulations and immune-related parameters of hemocytes in the green-lipped mussel Perna viridis. Fish Shellfish Immun.32(3): 381-390.

37. Ahuja, Y. R., \& Saran, R. (2001). Potential of single cell gel electrophoresis assay (comet assay) in heavy ion radiation biology. International Journal of Human Genetics, 1(2), 151-156.

38. Jaber, S., Mercier, A., Knio, K., Brun, S. and Kambris, Z. (2016). Isolation of fungi from dead arthropods and identification of a new mosquito natural pathogen. Parasites and Vectors 9(1): 491-495.

39. Senthilkumar, N., Murugesan, S. and Babu, D. S. (2014). Metabolite Profiling of the Extracts of Endophytic Fungi of Entomopathogenic Significance, Aspergillus flavus and Nigrospora sphaerica Isolated from Tropical Tree Species of India, Tectona grandisJ. Agri. Life Sci. 1(1): 108-114.

40. Bhan, S., Mohan, L. and Srivastava, C. N. (2015). Synergistic larvicidal potential of Temephos and entomopathogenic fungus, Aspergillus flavus against filarial vector, Culex quinquefaciatus (Say). J. Mosq. Res. 2(2): 33-37.

41. S. Environmental Protection Agency. 2003. Biopesticide registration action document Aspergillus flavus AF36. Available at: http://www.epa.gov/oppbppd1/biopesticides/ingredients/tech_docs/brad_ 
006456.pdf. Accessed 20 October 2009.

42. S. Environmental Protection Agency. 2004. Biopesticide registration action document Aspergillus flavus (NRRL 21882). Available at:http://www.epa.gov/oppbppd1/biopesticides/ingredients/tech_docs/ brad_006500.pdf. Accessed 20 October 2009.

43. Zhang, Y., Wang, Z. and Huang, D. (2001). Interrelation between carboxylesterase and glutathione-Stransferase in Apriona germari larvae and secondary metabolites of poplar trees. Scientia Silvae Sinicae 37(3): 106-111.

44. Gao, X. R., Cui, Y. L., Xu, F. H. and Li, R. F. (1995). The effects SOD scavenging O2-· as CAT existing. Journal of Heibei Normal University (Natur. Sci.)4: 59-62.

45. Ayala, A., Muñoz, M. F. and Argüelles, S. (2014). Lipid peroxidation: production, metabolism, and signaling mechanisms of malondialdehyde and 4-hydroxy-2-nonenal. Med. Cell Longev.2014: 11-19.

46. Mutyala, N. B. and Vadlamani, P. (2013). Induced oxidative stress by Metarhizium anisopliae instigates changes in lipid peroxidation and ultra structure in Periplaneta Americana. Afr J Microbiol Res 7(38): 4629-4637.

47. NarenBabu, M. and Padmaja,V. (2013). Induced oxidative stress by Metarhizium anisopliae instigates changes in lipid peroxidation and ultra structure in Periplaneta Americana. Afr. J. Microbiol. Res. 7(38): 4629-4637.

48. Jia, M., Cao, G., Li, Y., Tu, X., Wang, G., Nong, X. and Zhang, Z. (2016). Biochemical basis of synergism between pathogenic fungus Metarhizium anisopliae and insecticide chlorantraniliprole in Locusta migratoria (Meyen). Scientific Reports6: 28424-28434.

49. Chaurasia, A., Lone, Y., Wani, O. and Gupta, US. (2016). Effect of certain entomopathogenic fungi on oxidative stress and mortality of Periplaneta americana. Pesticide Biochemistry Physiology. Entomol. Zool. Stu. 4(1): 234-239.

50. Hyrsl, P., Buyukguzel, E. and Buyukguzel, K. (2007). The Effects of boric acid-induced oxidative stress on antioxidant enzymes and survivorship in Galleria mellonella. Insect. Physiol. 66: 23-31.

51. Barata, C., Lekumberri, I., Vila-Escalé, M., Prat, N. and Porte, C. (2005). Trace metal concentration, antioxidant enzyme activities and susceptibility to oxidative stress in the tricoptera larvae Hydropsyche exocellata from the Llobregat river basin (NE Spain). Toxicol.74(1): 3-19.

52. Aslanturk, A., Kalender, S., Uzunhisarcikli M, and Kalender, Y (2011). Effects of methidathion on antioxidant enzyme activities and malondialdehyde level in midgut tissues of Lymantriadispar (lepidoptera) larvae. Entomol. Res. Soc. 13(3): 27-38.

53. Karthi, S., Sankari, R. and Shivakumar, M. S. (2014). Ultraviolet-B light induced oxidative stress: effects on antioxidant response of Spodoptera litura. Photobiol. B135: 1-6.

54. Ali, A., Rashid, M. A., Huang, Q. Y. and Lei, C. L. (2017). Influence of UV-A radiation on oxidative stress and antioxidant enzymes in Mythimna separata (Lepidoptera: Noctuidae). Environ Sci. Pollut Res.24(9): 8392-8398.

55. Hoffmann, J. A. (1995). Innate immunity of insects. opin. immunol.7(1): 4-10.

56. Hoffmann, J. A. (2003). The immune response of Drosophila. Nature426(6962): 33. 
57. Gillespie, J. P., Burnett, C. and Charnley, A. K. (2000). The immune response of the desert locust Schistocerca gregaria during mycosis of the entomopathogenic fungus, Metarhizium anisopliae var acridum. Insect Physiol.46(4): 429-437.

58. da Silva, C., Dunphy, G. B. and Rau, M. E. (2000). Interaction of hemocytes and prophenoloxidase system of fifth instar nymphs of Acheta domesticus with bacteria. Comp. Immunol.24(4): 367-379.

59. Giulianini, P. G., Bertolo, F., Battistella, S. and Amirante, G. A. (2003). Ultrastructure of the hemocytes of Cetonischema aeruginosa larvae (Coleoptera, Scarabaeidae): involvement of both granulocytes and oenocytoids in in vivo phagocytosis. Tissue and Cel/35(4): 243-251.

60. Costa, S. C., Ribeiro, C., Girard, P. A., Zumbihl, R. and Brehélin, M. (2005). Modes of phagocytosis of Gram-positive and Gram-negative bacteria by Spodoptera littoralis granular haemocytes. Insect Physiol.51(1): 39-46.

61. Lavine, M. D. and Strand, M. R. (2002). Insect hemocytes and their role in immunity. Insect biochem. mol. bio.32(10): 1295-1309.

62. Gayfullina, L. R., Saltykova, E. S. and Nikolenko, A. G. (2006). Cellular immune reactions participating in resistance formation of Colorado beetle (Leptinotarsa decemlineata Say) larvae and imago to a biopreparation for potato. Resistant Pest Manage News/15: 22-24.

63. Begum, R. and Gohain, R. (1996). Detoxication of PP'DDT by the hemocytes of the fifth instar Philosamia ricini J. Environ Biol. 17(2): 149-155.

64. Fan, J. Q., Chen, X. R. and Hu, Q. B. (2013). Effects of destruxin A on hemocytes morphology of Bombyx mori. Integr. Agric.12(6): 1042-1048.

65. Falleiros, Â. M. F., Bombonato, M. T. S. and Gregório, E. A. (2003). Ultrastructural and quantitative studies of hemocytes in the sugarcane borer, Diatraea saccharalis (Lepidoptera: Pyralidae). Arch. Biol. Technol.46(2): 287-294.

66. Silva, J. E. B., Boleli, I. C. and Simões, Z. L. P. (2002). Hemocyte types and total and differential counts in unparasitized and parasitized Anastrepha obliqua (Diptera, Tephritidae) larvae. J. Biol.62(4A): 689699.

67. Baggio, M. V., Ferreira, M. D. C., Monteiro, A. C., Maldonado Junior, W. and Lemos, M. V. F. (2016). Pathogenicity of Aspergillus westerdijkiae to females and oothecae of Periplaneta Americana. Ciência Rural46(1): 20-25.

68. Duan, Y., Wu, H., Ma, Z., Yang, L. and Ma, D. (2017). Scanning electron microscopy and histopathological observations of Beauveria bassiana infection of Colorado potato beetle larvae. pathog.111: 435-439.

69. Ferrarese, R., Brivio, M., Congiu, T., Falabella, P., Grimaldi, A., Mastore, M., and Valvassori, R. (2005). Early suppression of immune response in Heliothis virescens larvae by the endophagous parasitoid Toxoneuron nigriceps. Surviv. J. 2(1): 60-68.

70. Habeeb, S. M. and El-Hag, H. A. (2008). Ultrastructural changes in hemocyte cells of hard tick (Hyalomma dromedarii: Ixodidae): a model of Bacillus thuringiensis thuringiensis H14;-endotoxin mode of action. Am-Euras J. Agric. Environ Sci.3: 829-836. 
71. Kaur, H. P., Singh, B., Thakur, A., Kaur, A. and Kaur, S. (2015). Studies on immunomodulatory effect of endophytic fungus Alternaria alternata on Spodoptera litura. Asia-Pacific Entomol.18(1): 67-75.

72. Raizada, R. B., Srivastava, M. K., Kaushal, R. A. and Singh, R. P. (2001). Azadirachtin, a neem biopesticide: subchronic toxicity assessment in rats. Food Chem. Toxicol.39(5): 477-483.

73. Boeke, S. J., Boersma, M. G., Alink, G. M., van Loon, J. J., van Huis, A., Dicke, M. and Rietjens, I. M. (2004). Safety evaluation of neem (Azadirachta indica) derived pesticides. Ethnopharmacol.94(1): 2541.

74. Derbalah, A. S. (2012). Efficacy of some botanical extracts against Trogoderma granarium in wheat grains with toxicity evaluation. The Sci. World J. 2012: 1-9.

75. Kognou, A. L. M., Tchamgoue, A. D., Tchokouaha, L. R. Y., Ngima, D., Nthenge-Ngumbau, P. V. T. F., Tchinda, A. T. and Gueiffier, C. E. (2018). Acute and sub-chronic toxicity studies of Dichaetanthera africana (Hook. F.) Jacq. Fel.(Melastomataceae) stem bark ethanol extract. Appl. Pharm. Sci.8(06): 147-155.

76. Sprando, R. L., Black, T., Olejnik, N., Keltner, Z., Topping, V., Ferguson, M. and Zheng, J. (2017). Assessing the effect of oral exposure to Paenibacillus alvei, a potential biocontrol agent, in male, nonpregnant, pregnant animals and the developing rat fetus. Food Chem. Toxicol.103: 203-213.

\section{Tables}

Table 1: Mortality of $S$. litura larvae fed on diet supplemented with different concentrations of $\boldsymbol{A}$. flavus.

\begin{tabular}{|ll|}
\hline $\begin{array}{l}\text { Concentrations } \\
(\mu \mathrm{g} / \mathrm{ml})\end{array}$ & $\begin{array}{l}\text { Larval mortality (\%) } \\
(\text { Mean } \pm S . E)\end{array}$ \\
\hline Control & $10.00 \pm 4.47^{\mathrm{a}}$ \\
125 & $16.66 \pm 8.02^{\mathrm{ab}}$ \\
250 & $26.66 \pm 4.21^{\mathrm{abc}}$ \\
\hline 500 & $36.67 \pm 6.15^{\mathrm{bcd}}$ \\
1000 & $43.33 \pm 5.24^{\mathrm{cd}}$ \\
\hline 2000 & $56.66 \pm 6.14^{\mathrm{d}}$ \\
\hline F value & $8.38^{\star \star}$ \\
\hline
\end{tabular}

$\star \star(p \leq 0.01)$

The values are mean \pm standard error. Different letters within the column are significantly different (Tukey's test, $p \leq 0.05$ ) and signify the effect of concentration. 
Table 2: Effect of different concentrations of ethyl acetate extract of $\boldsymbol{A}$. flavus on different parameters of comet assay in rat blood

\begin{tabular}{|c|c|c|c|c|c|c|c|}
\hline $\begin{array}{l}\text { Tail length } \\
(\mu \mathrm{m})\end{array}$ & 24 & 96 & $\begin{array}{l}\mathrm{t} \\
\text { value }\end{array}$ & $\begin{array}{l}\text { \% Tail } \\
\text { DNA }\end{array}$ & 24 & 96 & $\begin{array}{l}\mathrm{t} \\
\text { value }\end{array}$ \\
\hline Control & $14.57 \pm 0.18^{a}$ & $14.78 \pm 0.13^{a}$ & 1.48 & Control & $4.73 \pm 0.41^{\mathrm{a}}$ & $5.13 \pm 0.09^{a}$ & 0.58 \\
\hline $100 \mathrm{mg} / \mathrm{kg}$ & $14.84 \pm 0.21^{a}$ & $14.99 \pm 0.10^{\mathrm{a}}$ & 0.78 & $100 \mathrm{mg} / \mathrm{kg}$ & $4.84 \pm 0.02^{\mathrm{a}}$ & $5.19 \pm 0.23^{a}$ & 0.54 \\
\hline $200 \mathrm{mg} / \mathrm{kg}$ & $15.14 \pm 0.04^{\mathrm{a}}$ & $15.51 \pm 0.11^{b}$ & 1.40 & $200 \mathrm{mg} / \mathrm{kg}$ & $4.99 \pm 0.45^{a}$ & $5.52 \pm 0.18^{a}$ & 1.31 \\
\hline F value & 2.932 & $14.738 * \star$ & & F value & 1.130 & 1.378 & \\
\hline $\begin{array}{l}\text { Tail } \\
\text { Moment } \\
\text { (AU) }\end{array}$ & 24 & 96 & $\begin{array}{l}\mathrm{t} \\
\text { value }\end{array}$ & $\begin{array}{l}\text { Olive Tail } \\
\text { Moment } \\
\text { (AU) }\end{array}$ & 24 & 96 & $\begin{array}{l}\mathrm{t} \\
\text { value }\end{array}$ \\
\hline Control & $1.54 \pm 0.27^{a}$ & $1.64 \pm 0.32^{\mathrm{a}}$ & 0.48 & Control & $2.01 \pm 0.07^{a}$ & $2.14 \pm 0.15^{a}$ & 0.75 \\
\hline $100 \mathrm{mg} / \mathrm{kg}$ & $1.65 \pm 0.11^{\mathrm{a}}$ & $1.44 \pm 0.11^{\mathrm{a}}$ & 1.38 & $100 \mathrm{mg} / \mathrm{kg}$ & $2.11 \pm 0.05^{a}$ & $2.45 \pm 0.06^{a}$ & 19.27 \\
\hline $200 \mathrm{mg} / \mathrm{kg}$ & $2.02 \pm 0.10^{\mathrm{a}}$ & $2.33 \pm 0.15^{a}$ & 0.66 & $200 \mathrm{mg} / \mathrm{kg}$ & $2.25 \pm 0.01^{\mathrm{a}}$ & $2.78 \pm 0.29^{a}$ & 3.71 \\
\hline F value & 0.248 & 0.062 & & F value & 4.527 & 2.72 & \\
\hline
\end{tabular}

** $(p \leq 0.01)$, The values represented as mean \pm standard error. Different letters $a, b$ within the columns are significantly different (Tukey's test, $\mathrm{p} \leq 0.05$ ) and signify the effect of concentration.

Table 3: Effect of different concentrations of ethyl acetate extract of $\boldsymbol{A}$. flavus on different parameters of comet assay in rat liver 


\begin{tabular}{|c|c|c|c|c|c|c|c|}
\hline $\begin{array}{l}\text { Tail } \\
\text { Length } \\
(\mu \mathrm{m})\end{array}$ & 24 & 96 & $\begin{array}{l}\mathrm{t} \\
\text { value }\end{array}$ & $\begin{array}{l}\% \text { Tail } \\
\text { DNA }\end{array}$ & 24 & 96 & $\begin{array}{l}\mathrm{t} \\
\text { value }\end{array}$ \\
\hline Control & $12.44 \pm 0.15^{a}$ & $12.69 \pm 0.23^{a}$ & 5.55 & Control & $4.07 \pm 0.29^{a}$ & $4.22 \pm 0.23^{a}$ & 2.08 \\
\hline $100 \mathrm{mg} / \mathrm{kg}$ & $12.67 \pm 0.20^{a}$ & $12.84 \pm 0.33^{a}$ & 9.33 & $100 \mathrm{mg} / \mathrm{kg}$ & $4.62 \pm 0.22^{\mathrm{a}}$ & $4.78 \pm 0.11^{\mathrm{a}}$ & 21.56 \\
\hline $200 \mathrm{mg} / \mathrm{kg}$ & $13.03 \pm 0.27^{a}$ & $12.92 \pm 0.36^{\mathrm{a}}$ & 1.40 & $200 \mathrm{mg} / \mathrm{kg}$ & $4.79 \pm 0.25^{\mathrm{a}}$ & $4.64 \pm 0.21^{a}$ & 3.46 \\
\hline F value & 1.852 & 0.182 & & F value & 2.124 & 2.314 & \\
\hline $\begin{array}{l}\text { Tail } \\
\text { Moment } \\
(\mathrm{AU})\end{array}$ & 24 & 96 & $\begin{array}{l}\mathrm{t} \\
\text { value }\end{array}$ & $\begin{array}{l}\text { Olive Tail } \\
\text { Moment } \\
\text { (AU) }\end{array}$ & 24 & 96 & $\begin{array}{l}\mathrm{t} \\
\text { value }\end{array}$ \\
\hline Control & $1.16 \pm 0.15^{\mathrm{a}}$ & $1.34 \pm 0.14^{\mathrm{a}}$ & 0.84 & Control & $1.46 \pm 0.19^{a}$ & $1.44 \pm 0.18^{a}$ & 1.82 \\
\hline $100 \mathrm{mg} / \mathrm{kg}$ & $1.47 \pm 0.13^{\mathrm{a}}$ & $1.44 \pm 0.21^{\mathrm{a}}$ & 0.12 & $100 \mathrm{mg} / \mathrm{kg}$ & $1.52 \pm 0.07^{a}$ & $1.57 \pm 0.06^{a}$ & 17.50 \\
\hline $200 \mathrm{mg} / \mathrm{kg}$ & $1.31 \pm 0.10^{a}$ & $1.70 \pm 0.15^{a}$ & 2.07 & $200 \mathrm{mg} / \mathrm{kg}$ & $1.51 \pm 0.20^{a}$ & $1.85 \pm 0.03^{a}$ & 2.14 \\
\hline F value & 1.423 & 1.133 & & F value & 0.530 & 3.277 & \\
\hline
\end{tabular}

The values represented as mean \pm standard error. Different letters $a, b$ within the columns are significantly different (Tukey's test, $p \leq 0.05$ ) and signify the effect of concentration.

Table 4: Effect of different concentrations of ethyl acetate extract of $\boldsymbol{A}$. flavus on different parameters of comet assay in rat kidney 


\begin{tabular}{|c|c|c|c|c|c|c|c|}
\hline $\begin{array}{l}\text { Tail } \\
\text { Length } \\
(\mu \mathrm{m})\end{array}$ & 24 & 96 & $\begin{array}{l}\mathrm{t} \\
\text { value }\end{array}$ & $\begin{array}{l}\% \text { Tail } \\
\text { DNA }\end{array}$ & 24 & 96 & $\begin{array}{l}\mathrm{t} \\
\text { value }\end{array}$ \\
\hline Control & $14.95 \pm 0.22^{\mathrm{a}}$ & $15.16 \pm 0.39^{a}$ & 0.34 & Control & $4.74 \pm 0.14^{\mathrm{a}}$ & $4.53 \pm 0.04^{a}$ & 1.39 \\
\hline $100 \mathrm{mg} / \mathrm{kg}$ & $15.18 \pm 0.37^{\mathrm{ab}}$ & $15.21 \pm 0.15^{a}$ & 0.78 & $100 \mathrm{mg} / \mathrm{kg}$ & $4.96 \pm 0.09^{a}$ & $5.07 \pm 0.16^{b}$ & 0.54 \\
\hline $200 \mathrm{mg} / \mathrm{kg}$ & $15.38 \pm 0.02^{b}$ & $15.57 \pm 0.04^{a}$ & 0.43 & $200 \mathrm{mg} / \mathrm{kg}$ & $5.05 \pm 0.30^{\mathrm{a}}$ & $5.06 \pm 0.02^{b}$ & 0.36 \\
\hline F value & 0.717 & 0.842 & & F value & 0.640 & $9.92^{\star}$ & \\
\hline $\begin{array}{l}\text { Tail } \\
\text { Moment } \\
(\mathrm{AU})\end{array}$ & 24 & 96 & $\begin{array}{l}\mathrm{t} \\
\text { value }\end{array}$ & $\begin{array}{l}\text { Olive Tail } \\
\text { Moment } \\
(\mathrm{AU})\end{array}$ & 24 & 96 & $\begin{array}{l}\mathrm{t} \\
\text { value }\end{array}$ \\
\hline Control & $1.70 \pm 0.15^{a}$ & $1.72 \pm 0.16^{a}$ & 2.44 & Control & $1.93 \pm 0.32^{\mathrm{a}}$ & $2.01 \pm 0.31^{a}$ & 0.12 \\
\hline $100 \mathrm{mg} / \mathrm{kg}$ & $1.92 \pm 0.05^{\mathrm{a}}$ & $1.91 \pm 0.31^{\mathrm{a}}$ & 1.38 & $100 \mathrm{mg} / \mathrm{kg}$ & $1.99 \pm 0.01^{\mathrm{a}}$ & $1.96 \pm 0.35^{\mathrm{a}}$ & 19.72 \\
\hline $200 \mathrm{mg} / \mathrm{kg}$ & $2.12 \pm 0.13^{\mathrm{a}}$ & $2.31 \pm 0.09^{a}$ & 1.90 & $200 \mathrm{mg} / \mathrm{kg}$ & $2.10 \pm 0.15^{\mathrm{a}}$ & $2.17 \pm 0.17^{a}$ & 1.98 \\
\hline F value & 2.970 & 0.986 & & F value & 0.189 & 0.141 & \\
\hline
\end{tabular}

* $(p \leq 0.05)$. The values represented as mean \pm standard error. Different letters $a, b$ within the columns are significantly different (Tukey's test, $\mathrm{p} \leq 0.05$ ) and signify the effect of concentration.

\section{Figures}



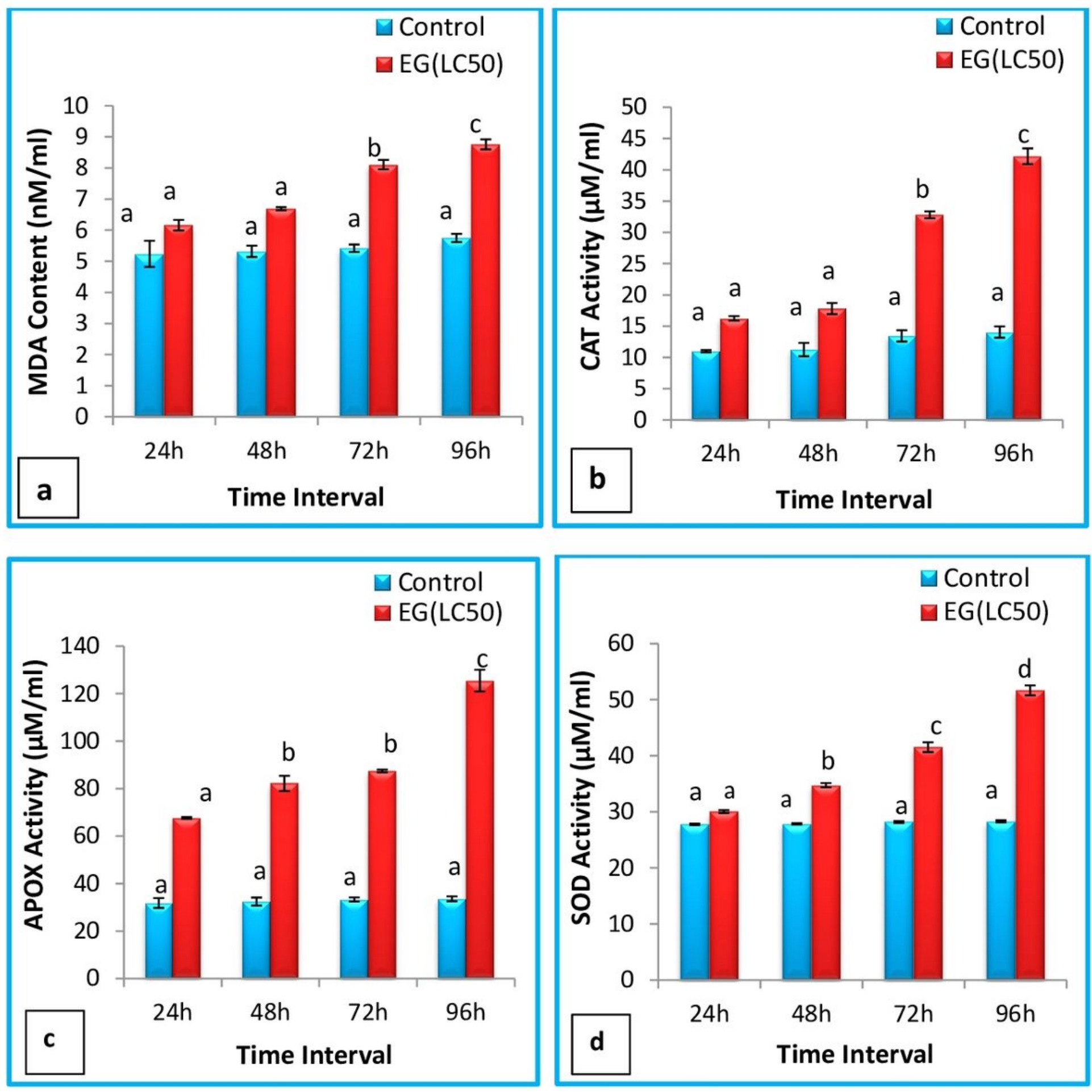

Figure 1

(a-d): Malondialdehyde (MDA) content (fig.1a), Catalase (CAT) activity (fig.1b), Ascorbate peroxidase (APOX) activity (fig.1c) and Superoxide dismutase (SOD) activity (fig.1d) in haemolymph of S.litura after treatment with ethyl acetate extract of A.flavus for different time intervals. EG = Exposed group. Bars represent mean $\pm S$.E. *Ascribes the significant difference between exposed group and control group (t-test, $p$ $\leq 0.05$ ). Different letters $a, b, c, d$ are significantly different (Tukey's test, $p \leq 0.05$ ) and signify the effect of duration. 

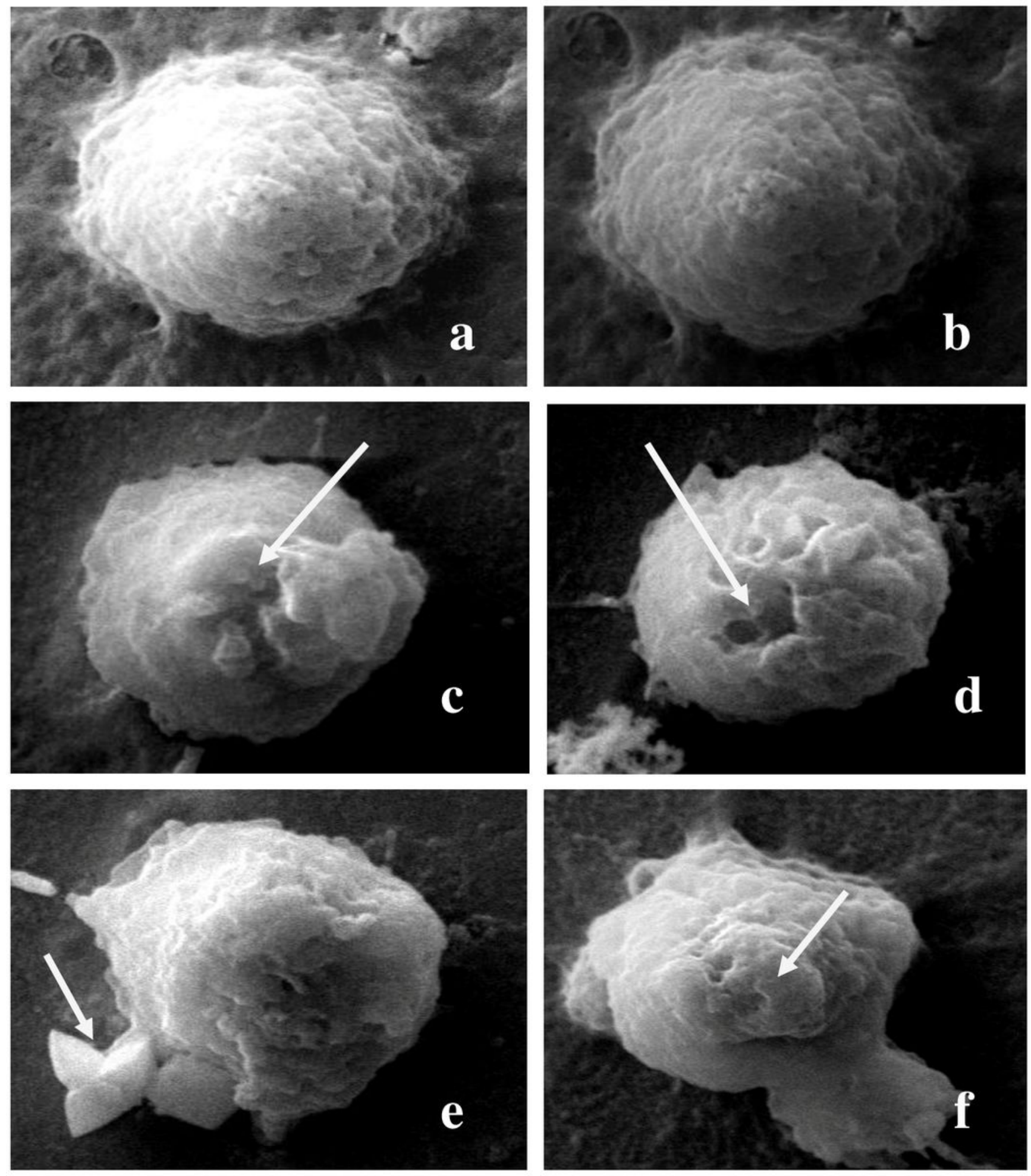

Figure 2

Microphotographs showing (a-b). Normal haemocytes (Group-1) (c-f). Various deformities observed in haemocytes after treatment with ethyl acetate extract of A. flavus (c-d). Cell perforation shown by arrow (ef). Cytoplasmic leakage shown by arrow 

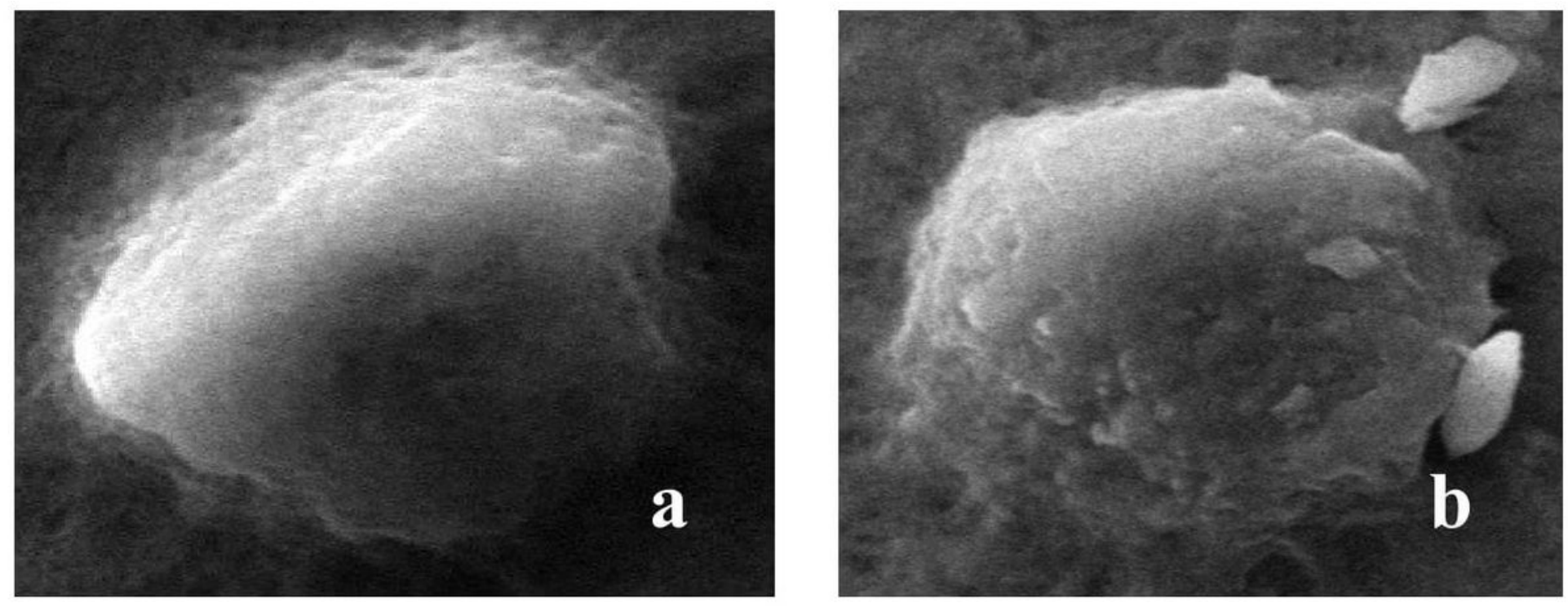

\section{Figure 3}

Microphotographs showing haemocytes (Group-2) (a). Normal haemocyte; (b). Strumae and surface abnormalities in haemocytes after treatment with ethyl acetate extract of A.flavus
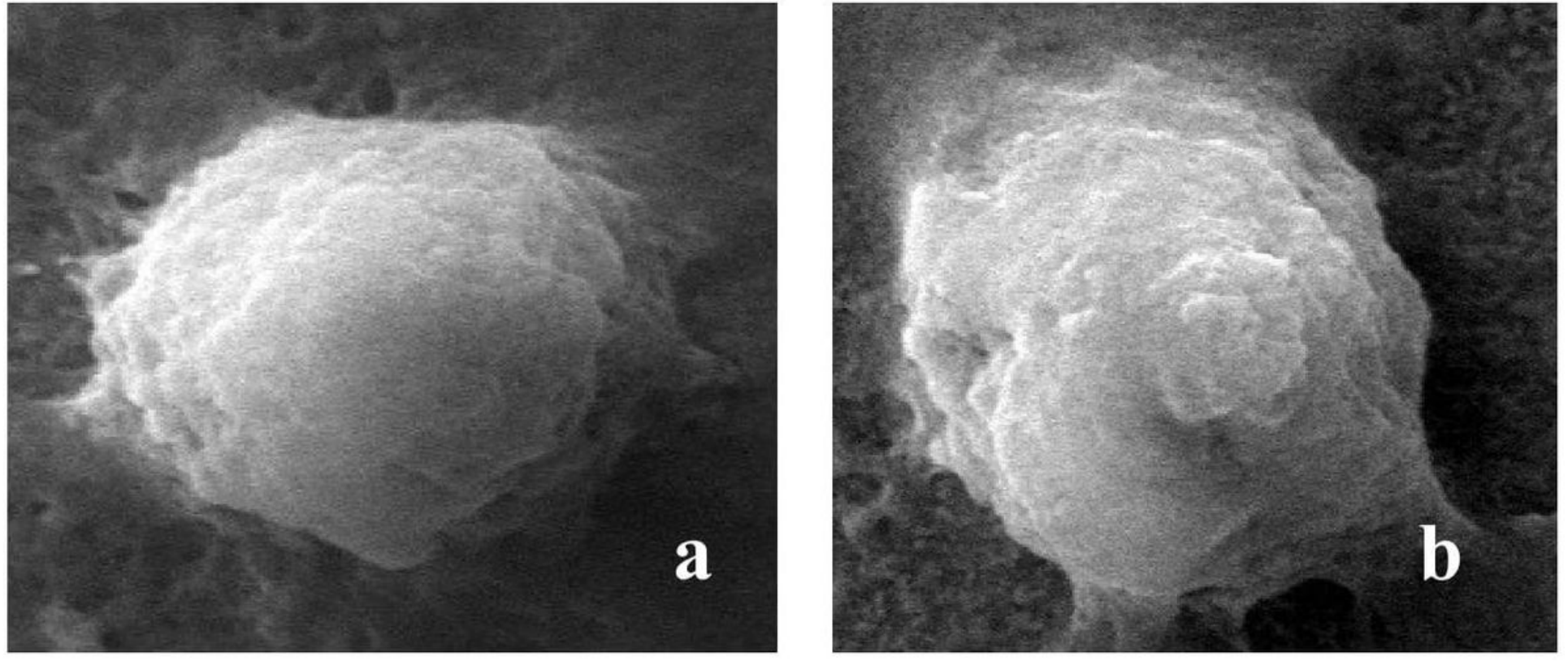

\section{Figure 4}

Microphotographs showing haemocytes (Group-3) (a). Normal haemocytes (b) surface abnormalities in haemocytes after treatment with ethyl acetate extract of A.flavus 


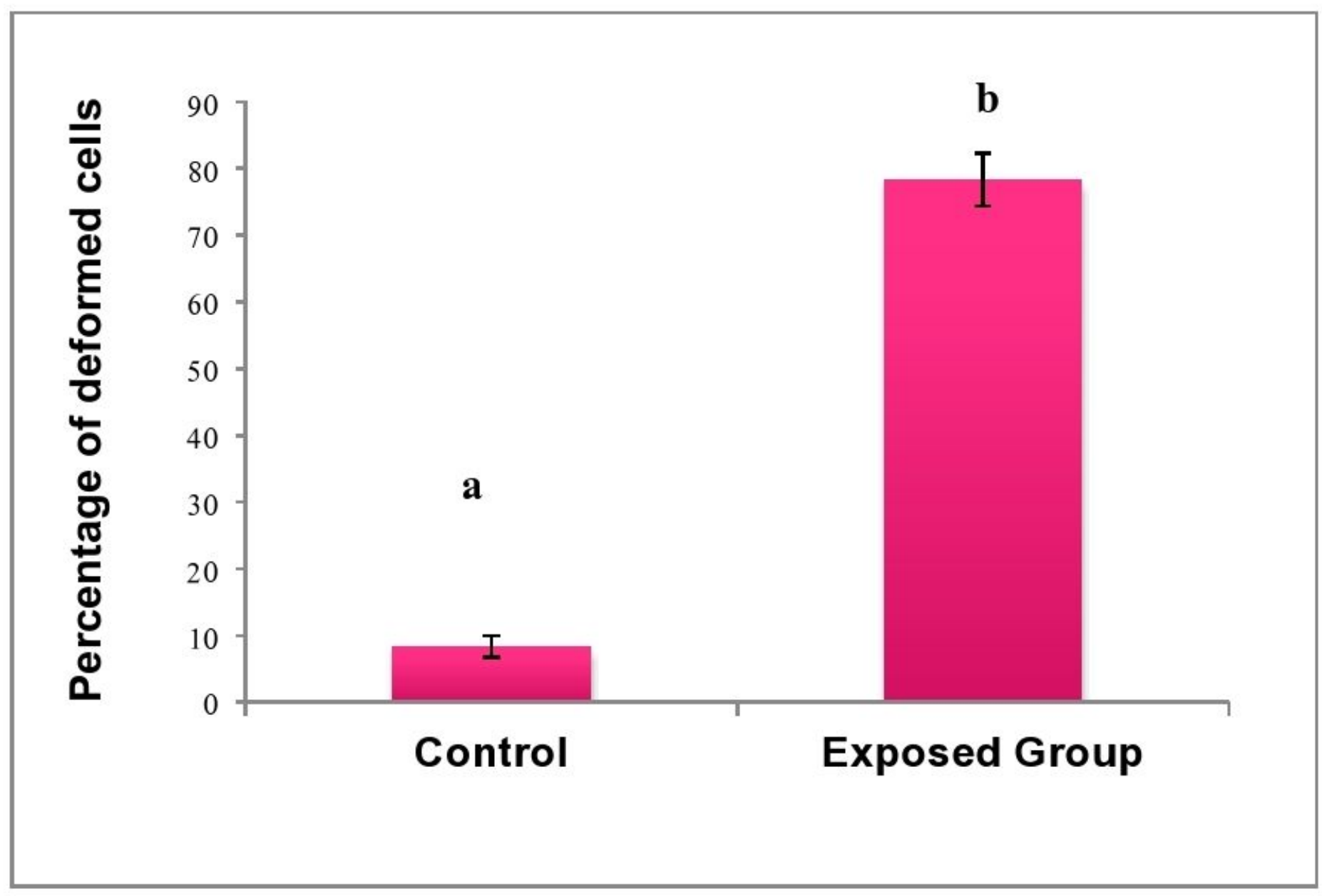

Figure 5

The percentage of cells showing various deformities 

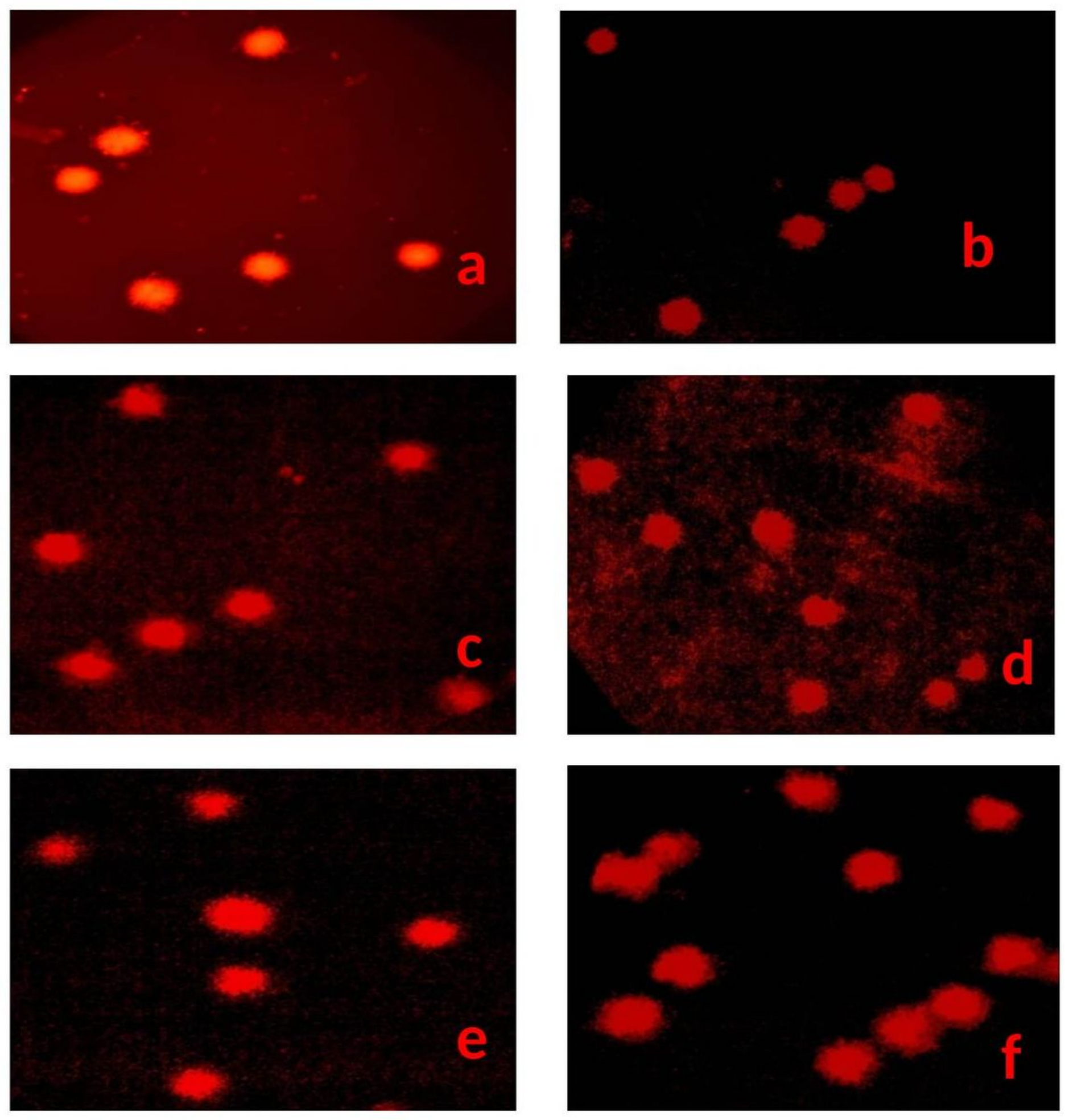

\section{Figure 6}

Photomicrographs showing DNA extracted from ( $a, b$ ) rat blood cells (a) Control; (b) After treatment with A.flavus ethyl acetate extract (c, d) rat kidney cells (a) Control; (b) After treatment with A.flavus ethyl acetate extract $(e, f)$ rat liver cells (a) Control; (b) After treatment with A.flavus ethyl acetate extract

\section{Supplementary Files}


This is a list of supplementary files associated with this preprint. Click to download.

- FigS1.docx 